\section{Nataša Živkovič}

Vrtec pri OŠ Istrskega odreda

Gračišče

natasa.zivkovic13@gmail.com

\section{Barbara Kopačin}

Univerza na Primorskem

barbara.kopacin@pef.upr.si
Zbornik povzetkov strokovne

konference Spodbujanje

učinkovitega učenja,

Koper, 26. avgust 2020

Abstracts of the Professional Conference Developing

Effective Learning,

Koper, 26 August 2020

\section{Spodbujanje govora z glasbenimi dejavnostmi}

Glasbena vzgoja se pri otroku lahko začne že pred rojstvom, ko je otrok še v materinem trebuhu, saj se slušno zaznavanje pri človeku pojavi zadnje štiri mesece bivanja v maternici. Takrat otrok že dobro sliši in se odziva na zvoke. Glasba nas tudi kasneje spremlja na vsakem koraku in njeni pozitivni učinki bogatijo otrokov celostni razvoj, saj se s pomočjo poslušanja, izvajanja in ustvarjanja glasbe otrok razvija na čustveno-motivacijskem, socialnem, spoznavnem in telesno-gibalnem področju. Aktivno ukvarjanje z glasbo naj bi bilo povezano tudi z uspešnostjo pri pouku, inteligentnostjo in s hitrejšim učenjem jezika. V šolskem letu 2019/2020 smo v dveh vrtcih na Primorskem v izvajanje različnih dejavnostih vseh predmetnih področij vpletali tudi glasbene dejavnosti. Predšolski otroci so vsak dan izvajali različne upevalne in govorne vaje, se premikali po prostoru v določenem ritmu ter hkrati izvajali ritmizirana besedila ob hkratnem izvajanju ritmičnega ostinata ali ritma izštevanke in druge glasbene dejavnosti. Otrokom se je do sredine marca bistveno podaljšal čas koncentracije. Usvojili so nekatere nove besede in si zapomnili večje število pesmi, izštevank in otroške poezije. Govor je postal bolj artikuliran in jasnejši, v izražanju so nekateri tujejezični otroci postali gotovejši v svoj drugi jezik, saj so ga usvojili preko igre oziroma glasbene dejavnosti. Raziskava kaže povezavo med ritmičnimi sposobnostmi in fonološkim zavedanjem. Učinki glasbenih dejavnosti niso omejeni samo na razvijanje glasbenih sposobnosti, temveč se zaradi analogije med glasbo in jezikom lahko prenesejo na jezikovno področje (fonološko zavedanje in kasneje branje). Glasbene dejavnosti so zelo učinkovite za učenje tako maternega jezika kot drugega jezika, kar je pomembno tudi za vse večje število tujejezičnih otrok v slovensko govorečih vrtcih.

Ključne besede: glasbene dejavnosti, govor, materni jezik, tuj jezik

\section{Encouraging Speech through Musical Activities}

Music education can start before birth, when the child is still in the womb, as auditory perception in humans occurs in the last four months of pregnancy. During this period, the child already hears well and responds to sounds. Music also accompanies us after birth and its positive effects enrich the child's holistic development, as it contributes to the emotional-motivational, social, cognitive and physical-motor capabilities through activities such as listening, performing and even creating music. Active involvement in music is also said to be associated with academic performance, intelligence and quicker language learning. During the school year 2019/2020 we enriched the implementation of various activities from all subject areas with additional music exercises in two nurseries in the Primorska region. Preschool children daily performed various singing and speaking exercises, moved around the room in a certain rhythm and sang accompanying lyrics while performing rhythmic ostinato or the rhythm of counting and other musical activities. By mid-March, the children's concentration time was significantly extended. The children learned some new words and memorised a large number of lyrics, counting rhymes and children's poetry. Speech became more articulate and clear, while some foreign-speaking children became more confident in their second language, as they learned it through play and musical activities. Research shows a link between rhythmic abilities and phonological awareness. The effects of musical activities are not limited to the development of musical abilities, but can be transferred to the linguistic field (phonological awareness and later reading) due to the analogy between music and language. Music activities are very effective for learning both the mother tongue and the second language, which is also important for the growing number of foreign children in Slovene nurseries.

Key words: musical activities, speech, mother tongue, foreign language 